\title{
Refleksi Isu Sosial Di Jepang Dalam Empat Karya Fiksi: Hiyama Kentarou No Ninshin, Sanjyu Mariko, Sensei No Kaban, Dan Death Sweeper
}

\author{
Budi Mulyadi, Yusifa Tamarlin Margie, Umar Bayu Wisesa \\ Program Studi S1 Bahasadan Kebudayaan Jepang, Universitas Diponegoro
}

Budi.mulyadi09@gmail.com

\begin{abstract}
This study examines how Japanese social issues are portrayed in four fiction works in the form of manga and novels:"Hiyama Kentarou no Ninshin", "Sanju Mariko", "Sensei no Kaban", and "Death Sweeper". Using qualitative methods by conducting descriptive analysis method to describe how social ties and community weakening in Japan in the scope of Shoushikoureika and Kodoku issues are portrayed in the said works. The finding sof this study are the followings: 1) Hiyama Kentarou no Ninshin portrayed the dilemma faced by women and men in child-bearing and child-rearing activities. 2) Sanju Mariko portrayed the vigor of Japanese elders and their struggle to find a place in society. 3) Sensei no Kaban portrayed the changes of Japanese narrowing social structure.4) Death sweeper portrayed lonely death as the effect of Kodoku. As a reflection of re ality, fiction works could also serve as a cross-cultural study by examining the phenomenon explained inside the works through the eyes of the writers and characters.
\end{abstract}

Keywords: Koreika; Kodoku; Shakai Mondai; Shoushika

\begin{abstract}
Abstrak
Penelitian ini mengkaji tentang bagaimana isu-isu sosial Jepang digambarkan dalamempat karya fiksi: Hiyama Kentarou no Ninshin, Sanju Mariko, Sensei no Kaban, dan Death Sweeper. Menggunakan metode kualitatif dengan melakukan metode analisis deskriptif untuk menggambarkan bagaimana pelemahan ikatan sosial dan komunitas di Jepang dalam lingkup isu Shoushikoureika dan Kodoku tergambar dalam karya-karya tersebut. Temuan dari penelitian ini adalah sebagai berikut: 1) Hiyama Kentarou no Ninshin menggambarkan dilema yang dihadapi oleh perempuan dan laki-laki dalam aktivitas mengasuh anak. 2) Sanju Mariko menggambarkan semangat orang tua Jepang dan perjuangan mereka untuk menemukan tempat di masyarakat.3) Sensei no Kaban menggambarkan perubahan struktur sosial Jepang yang semakin menyempit.4) Death Sweeper.menggambarkan kematian yang sepi sebagai efek Kodoku. Sebagai cerminan realitas, karya fiksi juga dapat menjadi kajian lintas budaya dengan menelaah fenomena yang dijelaskan di dalam karya tersebut melalui kacamata penulis dan tokohnya.
\end{abstract}

Kata kunci : Isu sosial, Karya fiksi; Koreika; Kodoku; Shoushika

\section{Pendahuluan}

Jepang merupakan salah satu negara dengan keberadaan yang besar di dunia, produk produk budaya Jepang dapat ditemui dan menjadi kegemaran di berbagai penjuru dunia.Hal ini tidak dapat lepas dari usaha promosi budaya besar-besaran yang terangkum dalam agenda Cool Japan. Cool Japan sendiri merupakan sebuah strategi yang ditujukan untuk membangun nation branding dan membina hubungan Jepang dengan negara lain dalam bidang ekonomi, kultural, dan diplomasi (Mustaqim, 2018). Usaha - usaha lain yang turut dilakukan Jepang juga termasuk pengadaan badan administratif berbadan hukum The Japan Foundation yang juga berada di Jakarta. The Japan Foundation turut aktif dalam 
mepromosikan kebudayaan Jepang dan mengadakan program pertukaran budaya. Sebagai hasil dari usaha - usaha tersebut Jepang kini menjadi negara yang terkenal dengan pandangan baik dalam masyarakat internasional.

Menurut data dari Spring 2018 Global Attitudes Survey oleh Pew Research Center (Stokes \& Devlin, 2018), negaranegara di Asia-Pasifik dan Amerika memiliki pandangan baik terhadap Jepang, dengan Filipina dan Australia sebagai yang paling tinggi dalam kecenderungan memandang Jepang secara positif. Diantara negara - negara tersebut, hanya Korea Selatan saja yang memiliki pandangan sebaliknya terhadap Jepang dengan $63 \%$ responden memandang Jepang secara negatif.Hal ini berkaitan erat dengan sejarah peperangan panjang antara Jepang dan Korea. Sebaliknya, Indonesia yang juga memiliki sejarah penjajahan oleh Jepang, mengalami perubahan pandang dan mulai berdamai dengan sejarah serta menyambut kerja sama dalam berbagai bidang dengan Jepang. Jepang kini merupakan mitra internasional yang penting bagi Indonesia, kemitraan dan citra baik Jepang turut mendorong banyaknya generasi muda yang ingin mempelajari berbagai hal mengenai negara ini.

Terlepas dari citra baik Jepang dalam masyarakat internasional, layaknya negara lain pada umumnya Jepang turut mengalami permasalahan dalam berbagai bidang. Salah satu jenis permasalahan pelik yang dialami Jepang selama dua dekade terakhir adalah isu sosial atau disebut juga Shakai Mondai. Organisasi non-profit CR Factory adalah salah satu lembaga yang aktif meneliti isu sosial di Jepang, dalam perjalan penelitiannya disebutkan ada dua faktor utama dari perkembangan isu sosial di Jepang yaitu; penurunan kualitas hubungan intrapersonal dan melemahnya komunitas(CR Factory, 2017).

Pada mulanya Jepang sendiri merupakan negara dengan sturuktur masyarakat komunal (masyarakat petani) yang menjalin erat hubungan dengan masyarakat di sekitarnya, namun seiring dengan modernisasi dan urbanisasi struktur ini semakin menyempit dan mengubah struktur keluarga dan hubungan masyarakat. Keadaan tersebut turut mempersempit ruang individu untuk berbagi beban di dalamnya sehingga penurunan kualitas hubungan serta melemahnya komunitas dapat terjadi. Beberapa isu yang berkaitan erat dengan fenomena ini adalah Shoushikoureika dan Kodoku. Shoushikoureika adalah gabungan dari dua istilah yaitu Shoushika atau penurunan angka kelahiran, dan koureika atau peningkatan jumlah lansia. Sedangkan kodoku sendiri berarti kesepian atau isolasi sosial.

Penurunan angka kelahiran di Jepang merupakan masalah yang menghantui Jepang selama dua dekade belakangan, dengan Total Fertility Rate (TFR) Jepang yang berada dibawah TFR standar yang diperlukan sebuah negara untuk pertumbuhan penduduk yang stabil. Shoushika sendiri merupakan hasil dari akumulasi beberapa faktor seperti bertambahnya masyarakat yang enggan menikah dan memiliki anak. Dalam keadaan kurangnya SDM yang dibutuhkan untuk stabilitas penduduk, dilain sisi Jepang merupakan negara dengan angka harapan hidup tertinggi sehingga berakibat dengan banyaknya lansia. Dari kedua fenomena ini terjadi lah ketimpangan jumlah masyarakat dependen dan ketersediaan SDM di masa depan. Permasalahan Shoushikoureika adalah permasalahan multidimensional yang mencakup berbagai aspek di Jepang, seperti ekonomi, peran sosial, struktur masyarakat, bahkan pemanfaatan ruang. Saat ini pemerintah telah mengerahkan berbagai kebijakan sebagai insentif dalam menghadapi permasalah Shoushikoureika, diantaranya adalah kebijakan paternity leave, womenomics oleh mantan Perdana Menteri Abe, penambahan batas usia pensiun, dan lainnya. 
Kodoku atau rasa sepi/kesepian adalah permasalahan abstrak yang terjadi di Jepang, meskipun kodoku dalam arti tunggalnya merupakan sebuah emosi, namun permasalahan mengenai rasa sepi atau kesepian ini diakui dengan munculnya perwujudan kodoku dalam berbagai isu sosial di Jepang, diantaranya hikikomori atau praktik pengasingan diri di Jepang; kodokushi atau lonely death; maupun kasus bunuh diri di Jepang. Saito melalui Kato, (2017) menyatakan dalam pedoman mengenai Hikikomori oleh Ministry of Labour, Health, and Welfare (MLHW) Jepang mendefinisikan Hikikomori sebagai keadaan dimana seseorang mengurung diri di rumah dan menolak berinteraksi termasuk kegiatan bersekolah dan bekerja selama lebih dari 6 bulan. Sedangkan Kodokushi atau lonely death adalah kead aan dimana seseorang meninggal dunia dalam keadaan terasingkan, dan biasanya jasadnya ditemukan dalam jangka waktu cukup panjang pasca kematian, keadaan ini biasanya di dominasi oleh kalangan lansia. Hal seperti Kodokushi menjadi umum terjadi bahkan di kalangan paruh baya atau dibawah 65 tahun(Kato, 2017). Fenomena ini pun turut disebabkan oleh perubahan struktur masyarakat seperti menurunnya tingkat interaksi individu dengan komunitas atau lingkungan tetangga, serta naiknya angka rumah tangga tunggal di Jepang (single person household). Menurut data tahun 2018 dari Cabinet Office Jepang (内 閣 府 Inaikakufu) dari 5.742 responden $67.7 \%$ menyatakan mereka terhubung dengan komunitas di daerah tempat tinggalnya, dengan proporsi $(18.3 \%$ terhubung dengan baik, $49.4 \%$ terhubung dengan agak baik), sedangkan $32.1 \%$ yang menjawab sebaliknya terdiri dari $(25.3 \%$ menjawab kurang terhubung serta $6.8 \%$ menjawab tidak berhubungan sama sekali), variabel dalam survei ini pun menunjukkan perbedaan tingkat hubungan dari perbedaan gender, rentang usia, kota, dan pekerjaan. Sedangkan menurut sensus kependudukan Jepang presentase rumah tangga tunggal terus menaiki kenaikan hingga angka $34.6 \%$ pada tahun 2015.

Isu - isu sosial di Jepang ini turut tertuang dalam berbagai media, salah satunya yaitu karya sastra. Permasalahan sosial yang sedang terjadi di Jepang turut mempengaruhi keputusan dan cara berpikir penulis dalam menghasilkan sebuah karya, ada kalanya bahkan seorang penulis menjadikan sebuah isu sosial sebagai tema utama dalam karya sastranya. Hal ini menunjukkan bahwa sastra bukan hanya sekedar hiburan melainkan juga sebagai refleksi dari realita yang terjadi di masyarakat. Swingewood melalui (Faruk, 2017:47) melacak usaha-usaha yang demikian jauh ke belakang, hingga terutama ke teori mimesis dari Plato. Menurut Plato, dunia dalam karya sastra merupakan tiruan terhadap dunia kenyataan yang sebenarnya juga merupakan tiruan terhadap dunia ide. Dengan demikian, apabila dunia dalam karya sastra membentuk diri sebagai dunia sosial, dunia tersebut merupakan tiruan terhadap dunia sosial yang ada dalam kenyataan sebagaimana yang dipelajari oleh sosiologi.

Sebagai salah satu produk kebudayaan di Jepang yang juga mengalami globalisasi seperti novel dan manga saat ini menjadi konsumsi bacaan yang dapat dinikmati oleh masyarakat Internasional. Sehingga melalui karya sastra masyarakat internasional dapat pula mendapat pengetahuan mengenai masalah yang terjadi di Jepang. Dalam penelitian ini akan meneliti proyeksi isu sosial dalam karya sastra Jepang melalui empat sampel judul yaitu manga Hiyama Kentarou no Ninshin (Eri Sakai) dengan proyeksi permasalahan shoushika, manga Sanju Mariko (Ozawa Yuki) dengan proyeksi koureika, serta manga Death Sweeper (Shou Kitagawa) dan Sensei no Kaban (Hiromi Kawakami) dengan proyeksi kodoku.

Ada beberapa penelitian karya sastra yang membahas tentang isu atau kritik sosial di Jepang yang direfleksikan 
lewat karya sastra baik berupa cerpen, novel, anime dan sebagainya. salah satunya adalah artikel jurnal yang berjudul kritik sosial terhadap pekerja di Jepang dalam cerpen Hen na Kusuri karya hoshi shinichi : kajian sosiologi sastra. Artikel ini ditulis oleh Wahyuningsih, menganalisis tentang kritik sosial terhadap pekerja di Jepang yang terkandung dalam cerpen Hen na Kusuri karya Hoshi Shinichi. Tujuan dari penelitiannya yaitu untuk mengungkapkan dan menjelaskan kritik sosial terhadap pekerja di Jepang berdasarkan analisis unsur-unsur instrinsik yang hanya dibatasi pada tema, tokoh dan penokohan, latar, serta alur melalui kajian sosiologi sastra. Data dari penelitian ini menggunakan cerpen Hen na Kusuri yang ditulis pada tahun 1971 oleh Hoshi Shinichi. Penelitiannya menggunakan metode deskriptif kualitatif. Persamaan dengan penelitian ini sama sama membagas tentang isu social yang direfleksikan dalam sebauah karya sastra. Perbed aannya terletak pada isi isu social serta objek material.

\section{Metode Penelitian}

Metode yang akan digunakan adalah metode kualitatif dengan mengambil sampel empat karya sastra yang berupa tiga buah manga yang berjudul Hiyama Kentarou no Nishin, Sanju Mariko, dan Death Sweeper serta satu buah novel yang berjudul Sensei no Kaban. Alasan untuk memilih keempat karya sastra ini yakni karena masing-masing karya memiliki tema atau isi plot yang dikelilingi isu sosial yang berada di Jepang. Hal ini dapat menjadi pembuktian bahwa karya sastra dapat dijadikan sebagai salah satu alternatif usaha pemahaman budaya suatu masyarakat bangsa. Adapun hubungan yang terbangun antara pembaca dengan dunia cerita dalam sastra adalah hubungan personal, sehingga karya sastra dianggap lebih bermakna dan menyentuh dibandingkan masalah yang sama yang dikemukakan secara lain (Nurgiyantoro, 1995). Penyajian datadalam penelitian ini dengan menggunakan metode deskriptif analitis. Penelitian deskriptif analitis mengambil masalah atau memusatkan perhatian kepada masalahmasalah sebagaimana adanya saat penelitian dilaksanakan, hasil penelitian yang kemudian diolah dan dianalisis untuk diambil kesimpulannya (Suratman, 2017, p. 33). Metode ini digunakan untuk mengidentifikasi dan menggambarkan fenomena-fenomena sosial di dalam masing-masing karya sastra yaitu yang menjadi refleksi masalah kehidupan di Jepang.

\section{Pembahasan dan Hasil}

\subsection{Shakai Mondai dalam Manga Hiyama Kentarou no Ninshin}

Hiyama Kentarou no Ninshin (Sakai, 2013) menceritakan tentang Hiyama Kentarou, seorang salaryman berusia 32 tahun yang mengalami baru saja mengetahui bahwa dirinya yang seorang laki-laki, ternyata hamil. Seri manga ini terdiri dari 5 episode ini menceritakan tentang dilema yang dihadapi dari sudut pandang orang-orang tertentu mengenai masalah kehamilan lakilaki.

Di dalam manga tersebut, diceritakan bahwa sudah 10 tahun sejak dunia pertama kali dikejutkan dengan fenomena laki-laki yang hamil. Meskipun demikian, penerimaan orang-orang terhadap "laki-laki yang hamil" masih belum baik. Ditambah lagi dengan cara berpikir orang Jepang tentang kehamilan itu sendiri. Masalah ini yang kemudian dihadapi oleh Hiyama Kentarou. Kentarou yang bekerja di perkantoran merasakan berbagai kendala yang dihadapi oleh seseorang yang sedang hamil. Selain itu, ia juga mulai mengerti perspektif teman kerjanya yang merupakan seorang wanita hamil. Lalu empat episode berikutnya menceritakan masalah kehamilan laki-laki dari perspektif seorang wanita pekerja yang bingung akan melakukan aborsi atau tidak; murid SMA laki-laki yang baru saja aborsi; 
wanita yang adalah ibu dari anak yang dikandung Kentarou; serta wanita yang memiliki seorang suami yang hamil.

Menurut Ogino, (1993:80-81) setidaknya ada beberapa faktor yang menyebabkan wanita di Jepang enggan untuk hamil. Pertama adalah faktor ekonomi. Masalah properti dan biaya untuk membesarkan anak membuat wanita Jepang berpikir dua kali untuk memiliki anak. Faktor kedua adalah mindset bahwa membesarkan anak hanya lah kewajiban wanita, yang mana ini menjadi beban yang terlalu berat bagi wanita Jepang.

Dari faktor ekonomi sendiri, terdapat beberapa lapis alasan yang memperkuat faktor tersebut, antara lain harga properti sebagai papan, biaya membesarkan anak, hingga masalah ketenagakerjaan ketika hamil maupun setelah mempunyai anak. Bagi wanita Jepang, hak mereka untuk cuti hamil tidak selalu diberikan, ini bergantung kepada tempat kerja macam apa yang wanita itu tempati. Sedangkan izin untuk mengurus anak ketika anak sakit juga kerap mendapat impresi miring dari para atasan.

\section{Dalam Hiyama Kentarou no} Ninshin episode pertama, gambaran wanita hamil yang masih tetap dipaksa masuk kerja diperlihatkan salah satu tokoh. Rekan kerja laki-laki menerima telepon rekan kerja wanita hamil yang meminta izin terlambat karena morning sickness namun malah mempertanyakan apakah wanita tersebut mengambil keuntungan dari kondisi hamilnya tersebut. Selain itu ia bahkan sempat menyalahkan pihak wanita karena ia hamil di bulan di mana perusahaan sedang sibuk. Kentarou yang mulai mengerti perspektif wanita hamil kemudian menangani hal tersebut sebagai atasan dengan mengizinkan wanita tersebut masuk ketika ia sudah membaik. Rekan laki-laki tersebut kemudian merasa kesal.

\section{Episode kedua dari Hiyama} Kentarou no Ninshin menjelaskan lebih dalam mengenai kekhawatiran seorang wanita yang sedang hamil dari segi ketenagakerjaan. Ia khawatir dengan berbagai masalah yang bisa timbul ketika ia hamil maupun setelah mempunyai anak. Seperti ketika tokoh tersebut melihat rekan wanita yang harus meminta izin pulang lebih awal karena menerima telepon dari tempat penitipan bahwa anaknya sakit. Atasan yang dimintai izin membolehkan meskipun dengan jawaban berupa kata "Lagi?" dan wajah yang kecewa. Lalu ketika ia ragu menerima tawaran bepergian menggunakan pesawat karena ia hamil, mempertimbangkan omongan orang mengenai wanita pekerja harus pensiun dan tidak bekerja setelah melahirkan, dan lain lain.

Pernikahan sering disebut sebagai faktor utama yang menentukan jumlah kelahiran (Widiandari, 2016:33). Di Jepang sendiri, pernikahan menghadapi masalahmasalah yang memperburuk fenomena shoushika. Salah satunya adalah fenomena bankonkadan minkonka.Josei Gaku Jiten melalui Parameshwara, (2019:2) menjelaskan bahwa bankoka adalah pernikahan pada usia yang lebih tinggi daripada usia ideal. Istilah bankoka juga bisa berarti penundaan pernikahan. Sedangkan minkonka adalah orang-orang yang memutuskan untuk tidak menikah. Orang-orang yang menunda maupun menghindari pernikahan akan secara langsung berdampak pada jumlah kehamilan yang mana akan juga berdampak pada jumlah kelahiran.

Dilansir dari Statistical Handbook of Japan 2020 oleh Biro Statistik Kementerian Dalam Negeri dan Komunikasi Jepang, pada tahun 2019 ratarata usia pernikahan pertama bagi laki-laki adalah 31.2 tahun dan 29.6 tahun bagi wanita, angka tersebut mengalami tren peningkatan dari tahun-tahun sebelumnya (30.5 untuk laki-laki dan 28.8 pada tahun 2010). Selain itu terdapat juga tren peningkatan presentase orang yang tidak menikah hingga usia 50 tahun, hingga 
mencapai puncaknya pada 2019 dengan $23.4 \%$ bagi laki-laki dan $14.1 \%$ bagi wanita.

Episode empat Hiyama no Ninshin menggambarkan bagaimana wanita Jepang melakukan minkonka. Seto Aki, seorang wanita pekerja lepas berumur 30 tahunan sedang membicarakan masalah anak bersama kedua temannya setelah merasa terganggu dengan suara anak-anak di bar tempat mereka bertemu. Ia akhirnya juga merasa risih dengan kedua temannya yang meskipun belum memiliki pasangan, tetapi ingin memiliki anak, berbeda dengan dirinya. Ia lebih nyaman berbicara dengan Kentarou, pria yang pernah ia jumpai di bar.

Dengan lantang ia katakan "Aku tak ingin punya anak karena sistem pensiun kita yang rusak!" dan "Berpikir bahwa menikah itu pasti bahagia adalah hal yang naif!' menjadi tandabahwa Aki jelas sekali menolak pernikahan. Hal ini menunjukkan fenomena minkonka dan bankoka yang terjadi di Jepang.

Pemerintah Jepang merespon shoushika dengan berbagai cara, salah satunya adalah dengan cuti kehamilan/maternity leave. Jepang mengatur urusan maternity leave ke dalam kebijakannya yang bertujuan untuk melindungi pekerja dari perlakuanperlakuan tidak menyenangkan bagi para pekerja yang mengambil cuti tersebut. Namun, dalam kenyataannya, tidak semua perusahaan sudah terbuka dengan hal tersebut, seperti yang digambarkan dalam Hiyama no Ninshin.

Dalam episode dua, ketika Kentarou berbicara dengan wanita pekerja hamil ini dan menanyakan apakah wanita tersebut sudah memberitahu tempat kerjanya tentang dirinya yang hamil, Kentarou khawatir apakah tempat kerja wanita tersebut adalah salah satu perusahaan "kuno" yang mengharuskan pekerjanya keluar setelah melahirkan. Kekhawatiran Kentarou menunjukkan masih adanya perusahaan-perusahaan yang tidak memberikan haknya kepada wanita hamil.

Tak hanya cuti kehamilan, Jepang juga merespon fenomena shoushika dengan kampanye ikumen. Ikumen merupakan singkatan dari iku (mengasuh) dan men (pria) sebuah istilah yang menggambarkan seorang pria yang menikmati masa pengasuhan anak (Muhayaroh, 2015:101). Kampanye ini adalah kampanye untuk mendukung pengasuhan anak oleh ayah yang diharapkan dapat mengurangi beban dari ibu sehingga para wanita mau untuk hamil dan melahirkan.

Dalam Hiyama Kentarou no Ninshin episode tiga, Tsubasa-tokoh yang menjadi sorotan dalam episode tersebutberbicara dengan Kentarou. Kentarou menjelaskan bahwa ia sedang mendesain sebuah restoran untuk dijadikan tempat di mana laki-laki hamil dan para ikumen bisa datang dan saling berbagi bantuan. Hal ini ia lakukan selain untuk mengurangi kesalahpahaman mengenai laki-laki hamil, juga membantu ayah yang mengasuh anak atau ikumen.

\subsection{Shakai Mondai dalam Manga Sanju Mariko}

Manga Sanju Mariko (Ozawa, 2016) merupakan manga yang menceritakan tentang seorang novelis perempuan bernama Mariko Kouda yang secara perlahan kemampuan fisiknya terdegradasi walaupun begitu beliau masih mampu menyokong perekonomian keluarganya hingga ia berumur 80 tahun, dengan kedua anak dan cucunya tinggal di dalam rumahnya. Meski begitu, nyatanya karena faktor umur, terkesan bahwa Mariko lah yang dependen dan membutuhkan kehadiran anggota keluarga lainnya. Manga ini menggambarkan fenomena koureika yang berhubungan erat dengan kehidupan lansia yang ingin independen di Jepang.

Di dalam manga ini diceritakan bahwa terdapat faktor utama yang menyebabkan masyarakat lansia ingin 
hidup mandiri, faktor tersebut adalah anggapan bahwa mereka dapat menjadi beban keluarga. Hal ini tergambarkan pada Chapter 1 dari kematian Junko yang diceritakan oleh Yaosaka (mantan suami Junko). Diceritakan bahwa kasus tersebut dapat dialami meskipun tinggal bersamaan dengan 4 generasi keluarga, sebagaimana hal ini mengindikasikan kerenggangan hubungan intrapersonal bahkan dalam keluarga di bawah satu atap. Sebagai pembelaan, anak Junko merasa bahwa ibunya selalu melakukan kegiatannya sendiri, ditambah lagi dengan pernyataan bahwa untuk mengurus lansia merupakan sebuah beban. Mariko yang tidak ingin mengalami kejadian serupa dengan temannya memutuskan untuk tinggal secara mandiri dengan maksud untuk mengurangi beban keluarga.

Pada Chapter 2, Mariko menemui seorang konsultan real-estate. PadaChapter ini dijelaskan dalam perkataan konsultan saat melayani Mariko, yang di mana diindikasikan bahwa belakangan ini banyak lansia yang ingin hidup sendiri dengan beberapa alasan, di antaranya ketidakmampuan untuk menyesuaikan diri dengan keluarga, dan keinginan untuk mendapatkan kebebasan di saat sedang hidup sendiri. Melanjutkan alasan banyaknya lansia yang ingin hidup mandiri, dalam prosesnya terdapat hambatan berupa diskriminasi. Tetapi diskriminasi itu sendiri dilatarbelakangi oleh alasan seperti ketidakinginan pemilik gedung/apartemen untuk mengambil resiko akan beban yang ditanggung, terutama dalam hal kesehatan lansia yang menjadi hambatan, seperti tanggungan penyakit, dan kodokushi.

Memasuki Chapter 4, dijelaskan bahwa sebelum lansia dapat memutuskan untuk hidup mandiri, ada 3 hal internal yang perlu diperhatikan, seperti niat, waktu dan uang. Terlepas dari hal internal, dalam menyewa tempat tinggal mendatangkan hambatan baru berupa dibutuhkannya campur tangan guarantor atau seseorang (biasanya kerabat atau teman dekat) yang menjamin dan bertanggung jawab secara finansial jika pihak asli gagal membayar. Mengingat ini Mariko harus kembali ke keluarga tempat ia tinggal sebelumnya untuk meminta tanda tangan dan orang yang menjamin kehidupan mandirinya.

Peristiwa di atas merupakan perwakilan after-effect dari kasus koureika yang dibahas dalam manga "Sanju Mariko". Dalam kasus koureika yang terjadi di Jepang dan yang diangkat dalam cerita manga "Sanju Mariko", lansia yang memilih untuk mengisolasi diri berangkat dari ketidakinginan mereka menjadi beban tanggungan keluarga. Dilansir dari RT Documentary tentang Kodokushi dari perspektif perusahaan jasa pembersih tahun 2019, seorang kakek bernama Toshio Sugano memutuskan untuk hidup sendiri karena alasan yang serupa dengan manga Sanju Mariko yakni ketidakinginan untuk menjadi beban keluarga.

Realitanya, kenaikan angka harapan hidup di Jepang berpengaruh dalam isu ini, Harapan hidup rata-rata di Jepang naik tajam setelah Perang Dunia II, dan saat ini berada pada level yang cukup tinggi di dunia. Menurut data dari Statistical Handbook of Japan tahun 2020 (Soomushootookeikyoku, 2020), Pada tahun 2010 angka harapan hidup untuk lakilaki sebesar 79,55 dan perempuan sebesar 86,30 . Kemudian di tahun terbitnya buku pada 2016, angka harapan hidup mengalami peningkatan menjadi 80,98 untuk laki-laki, dan 87,14 untuk perempuan, dan sampai saat ini angka harapan hidup Jepang terus meningkat. Dilansir dari japantimes.co.jp, Peningkatan tersebut terikat dengan kemampuan medis di Jepang dan menyebabkan adanya masalah-masalah spesifik, seperti naiknya kebutuhan lansia akan tempat tinggal. Tergambarkan pada kasus di kompleks apartemen Toei yang dikelola pemerintah kota Tokyo dengan 16 bangunan di sepanjang Sungai Sumida memiliki total 2.312 unit rumah. Yang di mana sekitar 38 persen rumah tangga dikepalai oleh orang-orang berusia di atas 
65 tahun, dibandingkan dengan 22 persen di seluruh Kelurahan Sumida.

Lalu mengenai bagaimana cara pemerintah Jepang memberikan penanggulangan isu banyaknya lansia yang memutuskan hidup sendiri sebenarnya sudah mulai diatur dalam beberapa kebijaksanaan yang dikeluarkan pemerintah, seperti Undang-undang Kesejahteraan Lansia (Roujin Fukushi Hou) dan Kesehatan Lansia (Roujin Houken Hou), Rencana Emas (Gold Plan), dan Asuransi Perawatan (Kaigo Houken) dari 1982-2000.

Gold Plan (Rencana Emas) yang merupakan rencana peningkatan pelayanan perawatan lansia yang ditetapkan sejak tahun 1989 merupakan undang-undang yang mengatur kebebasan lansia memiliki tempat tinggal. Rencana kesejahteraan dan perawatan kesehatan lansia mengalami perbaikan terus menerus. Pada tahun 2000 diberlakukan arah kebijaksanaan kesejahteraan sosial dan kesehatan lansia untuk 5 tahun mendatang yang dikenal dengan Rencana Emas 21 (Gold Plan 21).

Gold Plan 21 merupakan rencana peningkatan kesejahteraan dan kesehatan lansia yang ditetapkan pemerintah untuk menyempurnakan pelayanan perawatan lansia yang diberlakukan hingga kini. Salah satu konsep dasar pada Gold Plan 21 yang mendukung terealisasinya kepunyaan tempat tinggal terletak pada pernyataan "Memperbaiki pelayanan perawatan secara kuantitas dan kualitas agar lansia yang membutuhkan perawatan dapat hidup berkecukupan dan layak, serta memberi dukungan terhadap keluarganya"

Realisasi penggunaan asuransi perawatan dan Gold Plan 21 terangkum dalam jenis perawatan yang diberikan. Jenis perawatan tersebut adalah: Perawatan kunjungan rumah (layanan bantuan rumah), perawatan jalan (layanan harian), rehabilitasi jalan (perawatan harian), perawatan inap jangka pendek (inap jangka pendek), perawatan kunjungan mandi, kunjungan perawatan, kunjungan rehabilitasi, perawatan medis inap jangka pendek (inap jangka pendek), bimbingan perlindungan medis rumah, perawatan penanggulangan mobilitas lansia pikun (kelompok lansia pikun), dan bantuan pengadaan alat kesejahteraan dan kesehatan lansia.

Konsep dasar nomor 2 dan jenis perawatan kunjungan rumah (layanan bantuan rumah) diaplikasikan melalui Ministry of Health, Labour and Welfare of Japan (MHLW), yang di mana secara sistem sudah ada kebijakannya agar lansia mend apatkan tempat tinggal sendiri.

Prinsip dasar sistem asuransi perawatan jangka panjang adalah mendukung kemandirian lansia dan menjaga harkat dan martabatnya. Sistem tersebut hadir untuk memberikan pelayanan dan perawatan yang diperlukan lansia secara komprehensif dan terpadu ketika mereka berada dalam kondisi yang membutuhkan perawatan, sehingga mereka dapat hidup mandiri di rumah atau di lingkungan tempat tinggalnya. Sejak peluncuran sistem asuransi perawatan jangka panjang pada bulan April 2000, jumlah pengguna jasa (terutama layanan berbasis rumah) telah meningkat secara signifikan. Itu berakar di masyarakat sebagai sistem yang menjamin tahun-tahun pasca-pensiun yang nyaman. Sanju Mariko merefleksikan masyarakat lansia dengan keinginan tinggi untuk hidup mandiri di Jepang. Tindakan ini kini merupakan hal yang sebenarnya mendapat dukungan dari pemerintahan melalui beberapa kebijakan dan program yang telah dijabarkan sebelumnya, seperti penetapan undangundang, asuransi kesehatan, dan jaminan tempat tinggal. Meski begitu, hal ini tidak serta merta menyelesaikan permasalahan koureika, karena dari kebijakan yang ditetapkan pemerintah Jepang justru memulai menambah permasalahan kodokushi. 


\subsection{Shakai Mondai dalam Novel Sensei no Kaban}

Sensei no Kaban atau yang lebih dikenal dengan judul edisi terjemahan bahasa Inggris yaitu Strange Weather in Tokyo(Kawakami, 2001) adalah sebuah novel fiksi kontemporer karya Kawakami Hiromi yang diterbitkan pada tahun 2001. Novel ini bercerita tentang wanita bernama Tsukiko yang tidak sengaja bertemu kembali dengan guru sekolah menengah atasnya di suatu bar yang ia panggil dengan sebutan "Sensei" karena tidak mengingat nama aslinya. Melalui pertemuan tersebut, mereka mulai menjalin hubungan yang akrab seiring berjalannya waktu.

Walaupun fokus utama novel ini adalah perkembangan hubungan antara Tsukiko dan Sensei, namun pada beberapa tahap cerita terdapat narasi sudut pandang Tsukiko yang saat itu umurnya sudah mendekati 40 tahun yang sedang hidup seorang sendiri. Seperti yang dinarasikan oleh pengarang pada bab yang berjudul "Twenty-two Stars", meskipun ia sudah bertemu dengan Sensei, ia tidak merasakan hal yang berbeda seperti saat ia sendirian. Tsukiko tinggal jauh dari keluarganya sejak ia bekerja dan hanya mengunjungi keluarganya saat hari perayaan tertentu seperti hari tahun baru pada bab yang berjudul "New Year's". Setelah Tsukiko kembali ke apartemennya, ia kembali merasakan kesendirian. Hal-hal kecil sepele yang terjadi padanya seperti keliru dalam memotong apel saja dapat membuat Tsukiko menangis. Perasaan tersebut berlanjut sampai ia harus keluar di tengah malam yang dingin untuk menelusuri daerah sekitar, tetapi ia justru semakin merasa kesepian karena suasana yang sunyi dan sepi. Pada saat yang sama Tsukiko merenungkan kehidupannya selama ia tinggal sendiri, termasuk perpisahan dengan mantan kekasihnya yang menjadi salah satu faktor mengapa ia selalu larut dalam kesedihan saat sendirian. Namun setelah Tsukiko bertemu dengan Sensei, ia kembali seperti normal. Sensei pun juga tinggal seorang diri sejak istrinya meninggal, maka dari itu dari pertemuan mereka tersebut muncul sebuah simbiosis mutualisme dengan saling menemani satu sama lain dari kesendirian yang mereka hadapi pada fase usia tua.

Hal ini dapat diindikasikan bahwa Tsukiko dan Sensei adalah sebuah salah satu refleksi terhadap masyarakat Jepang yang mengalami fenomena sosial di era modern ini. Pada zaman sekarang, masyarakat Jepang telah mengalami pergeseran dalam pola berpikir yang akhirnya memberi pengaruh terhadap cara bertindak mereka. Pengaruh tersebut pada akhirnya memberikan perubahan pada struktur sosial di Jepang. Sebelum bangsa Jepang mengalami kekalahan pada Perang Dunia Kedua, setiap keluarga di Jepang umumnya merupakan Kakukazoku atau keluarga batih. Kakukazoku merupakan keluarga besar yang ditinggali tiga generasi, yaitu kakek-nenek, anak-ibu, dan anak. Namun pada kondisi masyarakat pada abad 21 yang melalui industrialisasi berubah dari masyarakat feodal hingga menjadi cenderung bermigrasi dari desa ke kota. Umumnya mereka meninggalkan keluarga untuk bekerja dan menetap di kota. Hal ini menyebabkan kecenderungan bahwa industrialisasi membuat seorang individu lebih dominan praktik dalam pekerjaan dibandingkan praktik interaksi sosial (Retnawati, 2013, pp. 9-10). Maka perubahan struktur sosial tersebut yang membuat banyak individu di Jepang memilih atau terpaksa untuk hidup seorang diri. Dalam angka kenaikannya, laki-laki yang hidup sendirian telah meningkat dari sekitar 190.000 jiwa menjadi 1,05 juta jiwa pada tahun 2005. Dalam kurun waktu yang sama, perempuan yang hidup sendirian juga meningkat dari sekitar 690.000 jiwa menjadi 2,81 juta jiwa (Thomas, 2008).

Meskipun hal tersebut membantu berjalannya roda ekonomi Jepang secara menyeluruh, namun di sisi lain juga memberi dampak buruk bagi masingmasing individual pekerja di Jepang yang 
berbentuk fenomena kesendirian atau yang disebut kodoku. Fenomena ini juga merupakan akar faktordari kodokushi, yaitu lonely death yang menjadi salah satu masalah sosial yang krusial di Jepang.

\subsection{Shakai Mondai dalam Manga Death Sweeper}

\section{MangaDeath}

Sweeper(Kitagawa,

2007)merupakan manga yang menceritakan tentang orang-orang yang bekerja di layanan jasa pembersih khusus, yang biasanya sering menangani kasus kematian lonely death. Setiap kasus kematian yang ditangani oleh para pekerja death sweeper ini memiliki cerita-cerita tersendiri yang berhubungan erat dengan kesepian dan kematian yang terisolasi.

\section{Orang-orang yang ditemukan} meninggal sendirian di dalam manga ini diceritakan bahwa mereka diindikasikan mengalami kesepian. Hal itu dapat diketahui dari perilaku atau perkataan mereka sebelum meninggal. Seperti misalnya, kasus kematian yang dialami oleh kakak dari pemeran utama, Okazaki, yang merupakan mantan mahasiswa kedokteran dengan kecerdasan di atas rata-rata. Orang tuanya memiliki harapan besar padanya atas kelebihannya tersebut. Namun, saat terakhir kali Okazaki bertemu dengannya, Ia berkata bahwa kecerdasan tidaklah berarti apa-apa apabila sudah menyangkut pada penderitaan. Banyak orang-orang cerdas yang memilih bunuh diri karena penderitaan yang mereka rasakan. Perkataannya mengindikasikan bahwa Ia selama ini mengalami kesepian karena tekanan dari orang tuanya yang hanya mengharapkan Ia untuk menjadi dokter yang hebat. Kakak Okazaki sendiri sudah memilih untuk keluar dari rumah dan memilih tinggal sendirian di sebuah apartemen sejak Ia memutuskan untuk berhenti kuliah kedokteran. Beberapa minggu setelah pertemuan terakhirnya dengan Okazaki, kakaknya ditemukan meninggal di atas kasur di dalam apartemennya. Karena kematian kakaknya,
Okazaki memutuskan untuk menjadi pekerja paruh waktu sebagai death sweeper. Okazaki bertemu dengan Miwa yang merupakan pekerja tetap sebagai death sweeper dan menjadi partner dalam menangani kasus-kasus lonely death.

Dalam kasus-kasus yang mereka tangani, orang-orang yang meninggal diindikasikan mengalami kesepian. Seperti seorang nenek berusia 70 tahun yang ditemukan meninggal di dalam bak mandi, yang menurut pemilik apartemen anakanaknya sudah tak mengunjunginya selama bertahun-tahun dan Ia ditinggalkan hidup sendiri. Lalu ada pula kasus seorang otaku yang ditemukan meninggal sendirian di dalam apartemennya yang dipenuhi oleh kaset-kaset video porno. Ibunya mengatakan bahwa putranya memilih untuk tinggal sendiri dan menjadi seperti ini sejak Ia bercerai dari ayahnya dan memilih menikah lagi dengan lelaki lain. Ia mengatakan bahwa dulu putranya sangat dekat dengan ayahnya, sehingga perceraiannya menjadi pukulan bagi putranya.

Kasus-kasus di atas merupakan perwakilan dari seluruh kasus yang dibahas dalam mangadeath sweeper yang korbannya terindikasi mengalami kesepian sebelum kematiannya.Weiss melalui Nurmina (2008:21)mendefinisikan kesepian sebagai suatu kondisi emosional negatif, dan biasanya orang yang mengalami kesepian merasa sendirian walaupun berada di tengah-tengah kerumunan atau keramaian. Kesepian tidak disebabkan oleh kesendirian melainkan oleh ketiadaan hubungan interpersonal yang jelas, akurat, dan sesuai dengan yang diharapkan. Kesepian yang dialami seseorang bisa diakibatkan oleh banyak hal. Dalam kasus lonely death yang terjadi di Jepang dan yang diangkat dalam cerita mangadeath sweeper, sebagian besar orang-orang yang mengalami kesepian karena mereka kehilangan ikatan emosi atau hubungan interpersonal dengan anggota keluarganya. Mereka merasa 
tertekan akan tuntutan dari keluarga, kekecewaan pada keluarga, dan tidak adanya kepedulian dari keluarga menyebabkan mereka mengalami kesepian dan memilih untuk mengisolasi diri. Hal tersebut kemudian menimbulkan masalah ketika mereka tiba-tiba meninggal didalam tempat tinggalnya sendiri tanpa diketahui oleh orang lain. Biasanya, orang-orang yang mengalami lonely death diketahui setelah adanya bau busuk di sekitar tempat tinggal mereka atau banyaknya seranggaserangga seperti lalat yang beterbangan di sekitar tempat tinggal mereka.

Orang yang pertama kali mengetahui bahwa ada seseorang yang meninggal di dalam apartemen biasanya adalah pemilik apartemen itu sendiri atau tetangga mereka. Sebagian besar dari mereka tidak berani untuk masuk dan mencari tahu sendiri, sehingga mereka memanggil jasa terkait untuk mencari tahu apakah benar di tempat tersebut ada seseorang yang meninggal. Hal itu karena mereka yang tinggal sendiri mengisolasi diri dan memutuskan kontak dengan keluarganya sehingga keluarganya tidak mengetahui apabila mereka sudah meninggal.

Kasus lonely death seperti ini di Jepang setiap tahunnya semakin bertambah. Menurut data dari Institut Penelitian NLI(Fifield, 2018), diperkirakan setiap tahunnya ada sekitar 30,000 orang yang meninggal secara lonely death. Hal ini menjadi masalah baru bagi pemerintah Jepang karena kasus kematian secara lonely death semakin bertambah setiap tahunnya. Selain bagi pemerintah Jepang, hal ini juga menjadi masalah bagi para pemilik apartemen karena apabila ada yang meninggal di bangunan mereka biasanya para penyewa yang lain akan memilih keluar dari apartemen tersebut karena merasa ketakutan. Hal itu juga kemudian membuat harga penyewaan apartemen tersebut mengalami penurunan drastis.
Semakin banyaknya kasus kematian lonely death kemudian memberikan dampak dalam kehidupan masyarakat dimana jasa pembersih khusus semakin dibutuhkan. Kebutuhan akan jasa ini kemudian menjadi industri baru di Jepang atas melonjaknya angka lonely death. Selain industri jasa pembersih khusus yang semakin menjamur akibat melonjaknya fenomena lonely death, perusahaanperusahaan asuransi juga membuat kebijakan baru untuk para pemilik apartemen. Kebijakan ini bertujuan untuk melindungi para pemilik apartemen apabila ada penyewanya yang meninggal secara lonely death. Kebijakan yang ditawarkan oleh perusahaan asuransi berupa penggantian biaya pembersihan dan kompensasi atas kehilangan biaya sewa.

Selain perusahaan asuransi yang mengubah kebijakan mereka akibat melonjaknya kasus lonely death, pemerintah Jepang juga mulai merencanakan kebijakan untuk mengatasi fenomena lonely death yang semakin meningkat. Dalam artikel dari sebuah jurnal yang berjudul "Governing through kodokushi. Japan's lonely deaths and their impact on community self-government" yang ditulis oleh Nils, (2020), pemerintah Jepang melalui Ministry of Labour, Health, and Welfare (MLHW) sudah merencanakan beberapa kebijakan yang dapat dilakukanuntuk mengatasi fenomena lonely death. Beberapa kebijakan yang dirancang oleh pemerintah Jepang seperti membangun hubungan sosial antar tetangga, memonitor orang-orang tua yang tinggal sendiri, dan juga menggunakan bantuan teknologi untuk mengobservasi perubahan kehidupan sehari-hari orang-orang yang tinggal sendiri. Membangun hubungan sosial antar tetangga merupakan kebijakan paling penting yang bisa mencegah pelonjakan angka kematian secara lonely death, sesuai dengan data yang telah tercantum pada latar belakang dalam penelitian ini. Hal ini berkaitan juga dengan budaya masyarakat Jepang yang sangat menjunjung tinggi 
Tersedia online di http://ejournal.undip.ac.id/index.php/kiryoku

privasi seseorang sehingga sering kali menimbulkan ketidakpedulian kepada orang lain terutama pada tetangga yang tinggal dalam satu gedung apartemen yang sama. Kebijakan ini diharapkan dapat membantu orang-orang yang tinggal sendiri agar tidak merasa khawatir apabila suatu saat mereka meninggal di dalam apartemen mereka. Selain itu, kebijakan ini tentunya diharapkan dapat membantu pemerintah dalam mengurangi lonjakan angka kasuskematian secara lonely death.

\section{Simpulan}

Dari hasil analisis dapat terlihat bahwa berbagai macam isu sosial di Jepang turut tertuang dalam karya sastra. Isu sosial yang terjadi dapat mempengaruhi keputusan dan cara berpikir penulis dalam menghasilkan sebuah karya. Ada kalanya bahkan penulis menjadikan sebuah isu sosial sebagai tema utama dalam karya sastranya seperti empat sampel karya yang dibahas dalam penelitian ini. Hiyama Kentarou no Ninshin, Sanju Mariko, Sensei no Kaban, dan Death Sweeper membahas sejumlah isu sosial yang sedang menjadi kekhawatiran di Jepang, seperti Shoushika, Koureika, dan Kodoku.

Lewat karya sastra secara langsung ataupun tidak langsung pembaca diperkenalkan dan bahkan diakrabkan dengan budaya masyarakat yang dijadikan setting karya sastra-yang bersangkutan. Hal ini bermanfaat untuk memahami budaya rnasyarakat di berbagai belahan dunia. Dari pemahaman antarbudaya itu selanjutnya diharapkan dapat muncul rasa saling menghormati sebagai prasyarat pergaulan antar manusia (Nurgiyantoro, 1995:16).

Oleh karena itu dengan banyaknya pembelajar sastra dan budaya Jepang dewasa ini, bahkan karya sastra fiksi pun dapat dijadikan sebagai media pembelajaran tentang sosial kultural negara terkait. Dengan karya sastra pembaca dapat pula memahami gejala sosial kultural didalamnya lewat sudut pand ang pengarang atau tokoh dalam karya. Namun hendaknya pembelajaran seperti ini diterapkan bersama pemeriksaan silang dengan faktafakta yang ada.

\section{DAFTAR REFERENSI}

CR Factory. (2017). Social Ties" and "Community" Weakening in Japan: CR Factory Community White Paper 2016 (1). Retrieved from https://www.jnpoc.ne.jp/en/reports/so cial-ties-and-community-weakeningin-japan-cr-factory-community-whitepaper-2016/\#_ftn3

Cabinet Office. (2018). Shakai ishiki ni kan suru yoron no chōsa [Survey on the public sentiments about social consciousness]. <URL:https://survey.govonline.go.jp/h29/h29-shakai/21.html>

Faruk. (2017). Pengantar Sosiologi Sastra (2nd ed.; R. Widada, Ed.). Yogyakarta: Pustaka Pelajar.

Fifield, A. (2018). Cleaning Up After The Dead. Retrieved December 8, 2020, from https://www.washingtonpost.com/new s/world/wp/2018/01/24/feature/somany-japanese-people-die-alonetheres-a-whole-industry-devoted-tocleaning-up-after-them/

Kato, T.A.; Shinfuku, N.; Sartorius, N.; Kanba, S. (2017). Loneliness and Single-Person Households: Issues of Kodokushi and Hikikomori in Japan. Mental Health and Illness in the City. Mental Health and Illness Worldwide. https://doi.org/https://doi.org/10.1007/ 978-981-10-2327-9_9

Kawakami, H. (2001). Sensei no Kaban. Tokyo: Heibonsha. Retrieved from 
https://www.worldcat.org/title/senseino-kaban/oclc/48484280

Kitagawa, S. (2007). Death Sweeper. Comic Charge. Retrieved from https://myanimelist.net/manga/17372/ Death_Sweeper

Muhayaroh, I. (2015). Fenomena Ikumen sebagai Salah Satu Perubahan Peran dan Identitas Ayah dalam Masyarakat Jepang Modern. Lingua Cultura, 9(2), 100.

https://doi.org/10.21512/lc.v9i2.823

Mustaqim, S. A. (2018). Upaya Jepang Dalam Mempopulerkan Program. 6(4), 1405-1418.

Nils, D. (2020). Governing through kodokushi. Japan's lonely deaths and their impact on community selfgovernment. Contemporary Japan, 32(1), 83-102. https://doi.org/10.1080/18692729.201 9.1680512

Nurgiyantoro, B. (1995). Sastra Sebagai Pemahaman Antarbudaya. Cakrawala Pendidikan Nomor 3, Tahlln XlY, November 1995, (November), 1-16.

Nurmina. (2008). Peran Persahabatan dan Harga Diri Terhadap Kesepian pada Remaja. Universitas Gadjah Mada.

Ogino, M. (1993). Japanese Women and the Decline of the Birth Rate.

Reproductive Health Matters, 1(1), 78-84. Retrieved from https://www.jstor.org/stable/3774858

Ozawa, Y. (2016). Sanju Mariko. Be-Love. Retrieved from https://myanimelist.net/manga/11136 5

Parameshwara, V. R. (2019). Bankonka dalam Perspektif Masyarakat Jepang. Universitas Bung Hatta.

Retnawati, D. (2013). Fenomena Kodokushi dalam Masyarakat Jepang. Universitas Indonesia.
Sakai, E. (2013). Hiyama Kentarou no Ninshin. Be-Love. Retrieved from https://www.cdjapan.co.jp/product/N EOBK-1392678

Soomushootookeikyoku. (2020). Statistical Handbook of Japan 2020. Retrieved from http://www.stat.go.jp/data/hand book/

Stokes, B., \& Devlin, K. (2018). Despite Rising Economic Confidence, Japanese See Best Days Behind Them and Say Children Face a Bleak Future. Pew Research Center, (November). Retrieved from https://www.pewresearch.org/global/2 018/11/12/despite-rising-economicconfidence-japanese-see-best-d aysbehind-them-and-say-children-face-ableak-future/

Suratman, D. (2017). Fotografi Sebagai Media Komunikasi Antar Persona dengan Pendekatan Nilai Keislaman (Pada Usia 18-25 Tahun Dalam Aplikasi Instagram). Universitas Pasundan.

Thomas, B. (2008). Kodokushi: tragedy of elder care in Japan - ChangingAging.

Widiand ari, A. (2016). Fenomena Shoushika Di Jepang: Perubahan Konsep Anak. Izumi, 5(1), 32. https://doi.org/10.14710/izumi.5.1.3239 